\title{
Calycomorphotria hydatis gen. nov., sp. nov., a novel species in the family Planctomycetaceae with conspicuous subcellular structures
}

\author{
Torsten Schubert • Nicolai Kallscheuer • Sandra Wiegand - Christian Boedeker • \\ Stijn H. Peeters • Mareike Jogler • Anja Heuer • Mike S. M. Jetten • \\ Manfred Rohde $\cdot$ Christian Jogler
}

Received: 27 January 2020/ Accepted: 15 April 2020/Published online: 12 May 2020

(C) The Author(s) 2020

\begin{abstract}
A novel strain belonging to the family Planctomycetaceae, designated $\mathrm{V} 22^{\mathrm{T}}$, was isolated from sediment of a seawater fish tank in Braunschweig, Germany. The isolate forms pink colonies on solid medium and displays common characteristics of planctomycetal strains, such as division by budding, formation of rosettes, a condensed nucleoid and presence of crateriform structures and fimbriae. Unusual invaginations of the cytoplasmic membrane and filamentous putative cytoskeletal elements were observed in thin sections analysed by transmission electron microscopy. Strain $\mathrm{V} 22^{\mathrm{T}}$ is an aerobic
\end{abstract}

T. Schubert · M. Jogler · C. Jogler $(\bowtie)$

Department of Microbial Interactions, Institute of

Microbiology, Friedrich Schiller University, Jena,

Germany

e-mail: christian@jogler.de

N. Kallscheuer - S. H. Peeters - M. S. M. Jetten ·

C. Jogler

Department of Microbiology, Radboud University,

Nijmegen, The Netherlands

S. Wiegand

Institute for Biological Interfaces 5, Karlsruhe Institute of

Technology, Eggenstein-Leopoldshafen, Germany

C. Boedeker · A. Heuer

Leibniz Institute DSMZ, Braunschweig, Germany

M. Rohde

Central Facility for Microscopy, Helmholtz Centre for

Infection Research, Braunschweig, Germany heterotroph showing optimal growth at $30{ }^{\circ} \mathrm{C}$ and $\mathrm{pH}$ 8.5. During laboratory cultivations, strain $\mathrm{V} 22^{\mathrm{T}}$ reached generation times of $10 \mathrm{~h}$ (maximal growth rate of $0.069 \mathrm{~h}^{-1}$ ). Its genome has a size of $5.2 \mathrm{Mb}$ and a $\mathrm{G}+\mathrm{C}$ content of $54.9 \%$. Phylogenetically, the strain represents a novel genus and species in the family Planctomycetaceae, order Planctomycetales, class Planctomycetia. We propose the name Calycomorphotria hydatis gen. nov., sp. nov. for the novel taxon, represented by the type strain $\mathrm{V} 22^{\mathrm{T}}$ (DSM $29767^{\mathrm{T}}=$ LMG 29080 ${ }^{\mathrm{T}}$.

Keywords Marine bacteria $\cdot$ Planctomycetes $\cdot$ Cell biology $\cdot$ Membrane invaginations $\cdot$ Aggregation

\section{Introduction}

Planctomycetes, an ubiquitous phylum of bacteria of mostly aquatic origin (Wiegand et al. 2018), comprises species with an uncommon physiology and morphology among bacteria (Lage et al. 2019; Wiegand et al. 2020). Phylogenetically, the phylum Planctomycetes, together with Chlamydiae, Verrucomicrobia and others, forms the PVC superphylum (van Niftrik and Devos 2017). The phylum Planctomycetes is subdivided into the classes Candidatus Brocadiae, Phycisphaerae and Planctomycetia. The taxonomy of the family Planctomycetia was recently revised, which led to further subdivision into the 
orders Gemmatales, Isosphaerales, Pirellulales and Planctomycetales (Dedysh et al. 2019b). Species of Candidatus Brocadiae are capable of performing anaerobic ammonium oxidation (anammox) (Strous et al. 1999) and thereby convert ammonium to dinitrogen gas (Peeters and van Niftrik 2018). Members of the class Planctomycetia have been isolated from various aquatic biotic and abiotic surfaces in the past decade (Boersma et al. 2019; Bondoso et al. 2014, 2017; Kallscheuer et al. 2020; Peeters et al. 2020; Vollmers et al. 2017). Such species can be highly abundant on marine biotic surfaces, e.g. on macroscopic phototrophs (Bengtsson and Øvreås 2010). Since oceans are typically oligotrophic, species of the class Planctomycetia probably digest complex carbon substrates derived from the biotic surfaces to which they are attached (Jeske et al. 2013; Lachnit et al. 2013). For this purpose, they may utilise a specialised machinery for the uptake and intracellular digestion of complex polysaccharides (Boedeker et al. 2017), which could be a decisive advantage during competition for nutrients in their natural habitats.

In recent years, microscopic techniques and genetic tools (Jogler et al. 2011; Jogler and Jogler 2013; RivasMarin et al. 2016) have enabled a detailed analysis of the cell envelope architecture of Planctomycetes. Both, Planctomycetes and Verrucomicrobia, were shown to possess peptidoglycan (Jeske et al. 2015; Rast et al. 2017; van Teeseling et al. 2015). The cell envelope architecture of Planctomycetes is therefore similar to that of Gram-negative bacteria (Boedeker et al. 2017; Devos 2014a, b). Nevertheless, Planctomycetes display uncommon cell biological features, e.g. with regard to their mode of cell division. Members of the class Planctomycetia divide by budding, whereas Phycisphaerae divide by binary fission. Some species probably even switch between both modes of division (Wiegand et al. 2020). All characterised members of the phylum lack canonical divisome proteins including the otherwise universal FtsZ (Jogler et al. 2012; Pilhofer et al. 2008). The sizes of planctomycetal genomes range between 3 and $12 \mathrm{Mb}$ (Ravin et al. 2018; Wiegand et al. 2018), while typically $40-55 \%$ of the gene products are annotated as hypothetical or uncharacterised proteins. Given such values, Planctomycetes represent an attractive subject for future research.

Here, we describe a novel strain, $\mathrm{V} 22^{\mathrm{T}}$, isolated from sediment of a seawater fish tank in
Braunschweig, Germany. According to the results of our analysis, the strain represents a novel species and genus in the recently revisited family Planctomycetaceae, order Planctomycetales in the class Planctomycetia (Dedysh et al. 2019b).

\section{Material and methods}

Isolation of the novel strain and cultivation

For the isolation and cultivation of strain $\mathrm{V} 22^{\mathrm{T}}$, M1H NAG ASW medium was prepared as described by Boersma et al. (2019). Sediment and water from a seawater fish tank in Braunschweig, Germany (location: $52.2689 \mathrm{~N} 10.5268 \mathrm{E})$ were mixed by shaking and the water was subsequently plated on M1H NAG ASW plates containing $8 \mathrm{~g} / \mathrm{L}$ gellan gum, $1000 \mathrm{mg} / \mathrm{L}$ streptomycin, $200 \mathrm{mg} / \mathrm{L}$ ampicillin and $20 \mathrm{mg} / \mathrm{L}$ cycloheximide, which were then incubated at $20{ }^{\circ} \mathrm{C}$ for several weeks. In order to verify that obtained strains are members of the phylum Planctomycetes, the 16S rRNA gene was amplified using colony-PCR and subsequently sequenced as previously described (Rast et al. 2017).

Determination of $\mathrm{pH}$ and temperature optimum

Cultivations for determination of the $\mathrm{pH}$ optimum were performed in $\mathrm{M} 1 \mathrm{H}$ NAG ASW medium. A concentration of $100 \mathrm{mM}$ 4-(2-hydroxyethyl)-1-piperazineethanesulfonic acid (HEPES) was used for cultivations at $\mathrm{pH} 7,7.5$ and 8 . For cultivation at $\mathrm{pH}$ 5 and 6, HEPES was replaced by $100 \mathrm{mM} 2-(N-$ morpholino)ethanesulfonic acid (MES), whereas $100 \mathrm{mM} \mathrm{N}$-cyclohexyl-2-aminoethanesulfonic acid (CHES) served as a buffering agent at $\mathrm{pH} 9$ and 10. Cultivations for determination of the $\mathrm{pH}$ optimum were performed at $28{ }^{\circ} \mathrm{C}$. Cultivations for determination of the temperature optimum were performed in standard M1H NAG ASW medium at pH 7.5.

\section{Microscopy protocols}

Phase contrast and field emission scanning electron microscopy were performed as previously described (Boersma et al. 2019). Thin sectioning, subsequent staining and transmission electron microscopy (TEM) 
were performed as previously described (Jogler et al. 2011).

\section{Genome information}

The genome sequence of strain $\mathrm{V} 22^{\mathrm{T}}$ is available from GenBank under accession number CP036316. The 16S rRNA gene sequence of strain $\mathrm{V} 22^{\mathrm{T}}$ can be found under accession number MK554537. Sequencing of the genome of strain $\mathrm{V} 22^{\mathrm{T}}$ is described in a previously published study (Wiegand et al. 2020). Numbers of carbohydrate-active enzymes were obtained from the CAZY database (Lombard et al. 2014). Gene clusters potentially involved in the production of secondary metabolites were determined using antiSMASH 4.0 (Blin et al. 2017).

\section{Phylogenetic analysis}

16S rRNA gene sequence-based phylogeny was computed for strain $\mathrm{V} 22^{\mathrm{T}}$, the type strains of all described planctomycetal species (assessed in January 2020) and all isolates recently published and described (Boersma et al. 2019; Dedysh et al. 2019a, b; Kallscheuer et al. 2019a, b, 2020; Kohn et al. 2019; Peeters et al. 2020; Rensink et al. 2020). The 16S rRNA gene sequences were aligned with SINA (Pruesse et al. 2012) and the phylogenetic inference was calculated with RAxML (Stamatakis 2014) with a maximum likelihood approach with 1000 bootstraps, nucleotide substitution model GTR, gamma distributed rate variation and estimation of proportion of invariable sites (GTRGAMMAI option). For the multi-locus sequence analysis (MLSA) the unique single-copy core genome of the analysed genomes was determined with proteinortho5 (Lechner et al. 2011) with the 'selfblast' option enabled. The protein sequences of the resulting orthologous groups were aligned using MUSCLE v.3.8.31 (Edgar 2004). After clipping, partially aligned $C$ - and $N$-terminal regions and poorly aligned internal regions were filtered using Gblocks (Castresana 2000). The final alignment was concatenated and clustered using FastTree (Price et al. 2009). The average nucleotide identity (ANI) was calculated using OrthoANI (Lee et al. 2016). The average amino acid identity (AAI) was calculated using the aai.rb script of the enveomics collection (Rodriguez-R and Konstantinidis 2016) and the percentage of conserved proteins (POCP) was calculated as described (Qin et al. 2014). The $r p o B$ nucleotide sequences were taken from publicly available planctomycetal genome annotations and the sequence identities were determined as described (Bondoso et al. 2013). Upon extracting only those parts of the sequence that would have been sequenced with the described primer set, the alignment and matrix calculation was performed with Clustal Omega (Sievers et al. 2011).

\section{Results and discussion}

Phylogenetic inference

Based on 16S rRNA gene phylogeny (Fig. 1a), strain $\mathrm{V} 22^{\mathrm{T}}$ belongs to the recently redefined family Planctomycetaceae, the sole family in the order Planctomycetales (Dedysh et al. 2019b). This family is currently formed by eight genera, namely Gimesia, Planctomyces, Planctopirus, Schlesneria, Planctomicrobium, Rubinisphaera, Fuerstiella and Alienimonas. Within this family, the current closest relative of strain $\mathrm{V} 22^{\mathrm{T}}$ is Alienimonas californiensis $\mathrm{CA} 12^{\mathrm{T}}$ (Boersma et al. 2019) as determined by both $16 \mathrm{~S}$ rRNA gene analysis and MLSA (Fig. 1b). Strain V22 ${ }^{\mathrm{T}}$ shares a $16 \mathrm{~S}$ rRNA gene identity of $85.2 \%$ with $A$. californiensis, a value clearly below the genus threshold of $94.5 \%$ and even slightly below the family threshold of $86.5 \%$ (Yarza et al. 2014). This strongly supports delineation of strain $\mathrm{V} 22^{\mathrm{T}}$ from the genus Alienimonas. In order to substantiate the delineation from known genera additional phylogenetic markers were taken into consideration, e.g. AAI, $r p o B$ similarity and POCP. Similarity values obtained during comparison of strain $\mathrm{V} 22^{\mathrm{T}}$ with A. californiensis and Planctomicrobium piriforme, a second close relative, are below the genus threshold values applied for $r p o B$ (75.5-78.0\%) (Kallscheuer et al. 2019b), AAI (60-80\%) (Konstantinidis and Tiedje 2005), and POCP (50\%) (Qin et al. 2014) (Fig. 2). ANI values of $67.2 \%$ and $67.1 \%$ confirm that strain $\mathrm{V} 22^{\mathrm{T}}$ does not belong to A. californiensis or $P$. piriforme. Hence, all used methods support the delineation of strain $\mathrm{V} 22^{\mathrm{T}}$ from members of already described genera in the family Planctomycetaceae. 


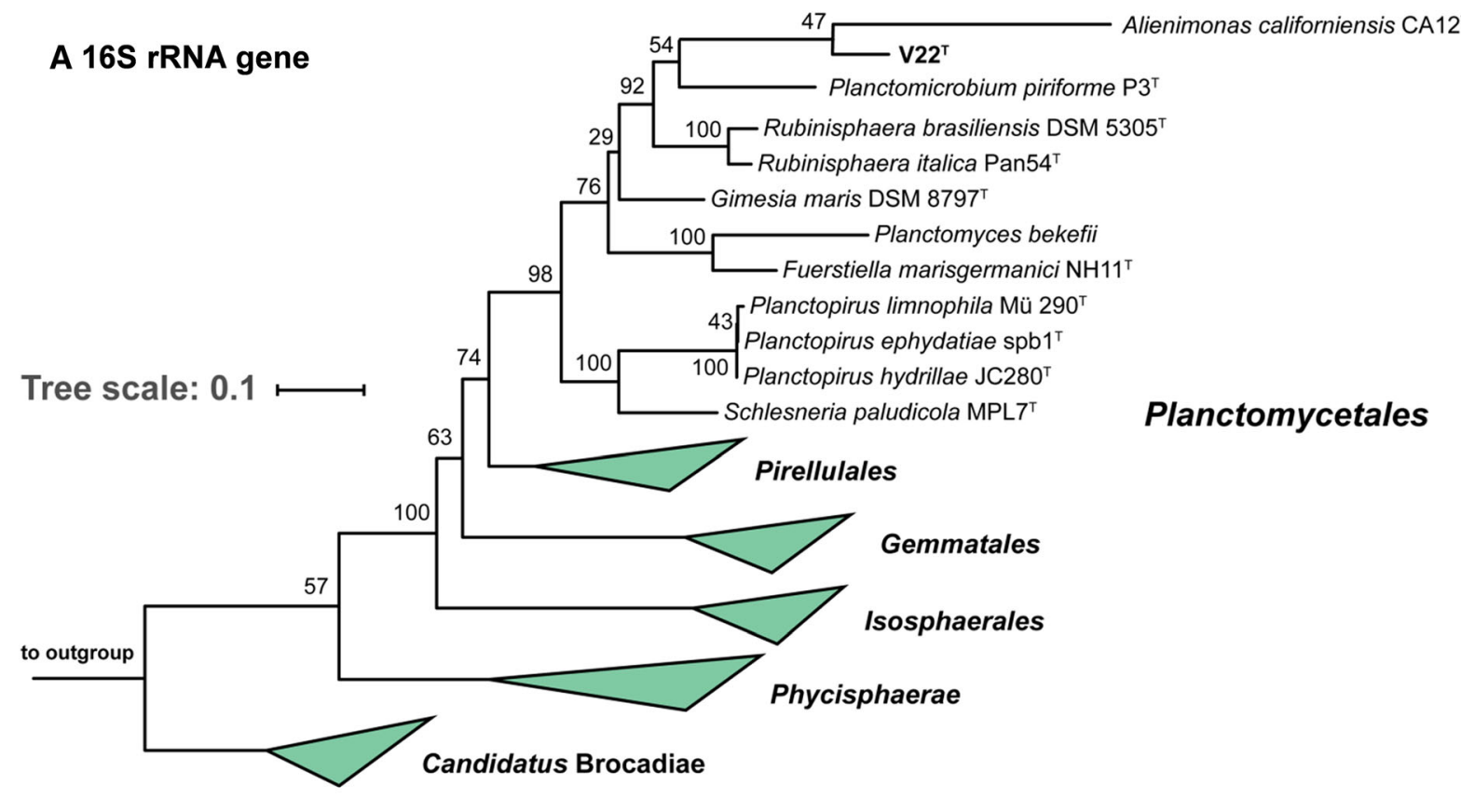

\section{B MLSA}

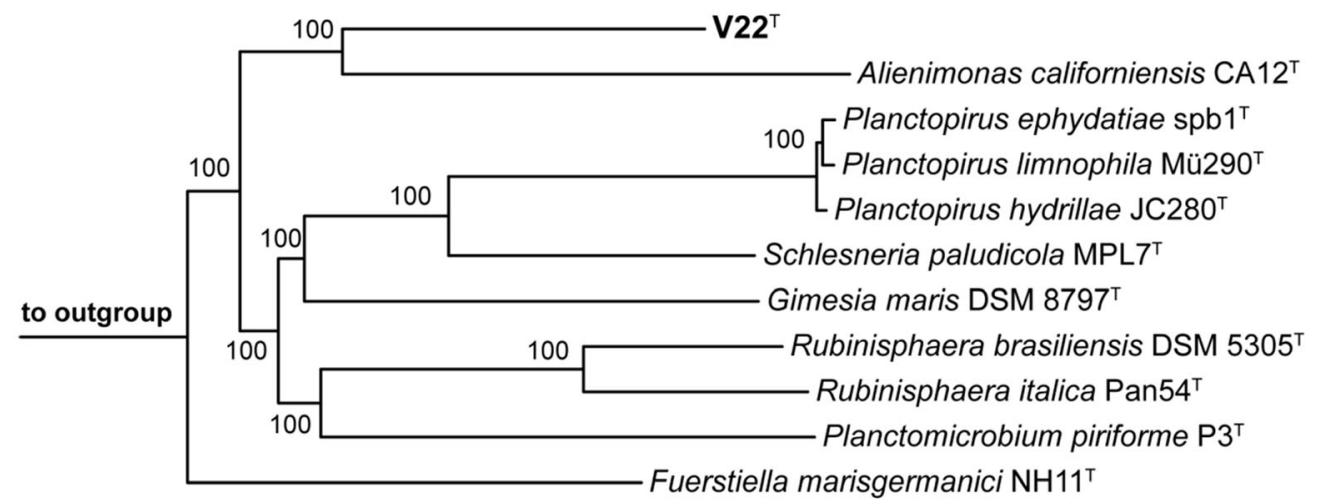

Tree scale: 0.1

Fig. 1 Maximum likelihood phylogenetic analysis. Phylogenetic tree showing the position of strain $\mathrm{V} 22^{\mathrm{T}}$. $16 \mathrm{~S}$ rRNA gene sequence- and MLSA-based phylogeny was computed as described in the Material and Methods section. Bootstrap values after 1,000 re-samplings (16S rRNA-based tree) are given at the nodes (in \%). The outgroup consists of three 16S rRNA genes

Morphological, physiological and biochemical analyses

Basic features of strain $\mathrm{V} 22^{\mathrm{T}}$ including cell morphology, growth and mechanism of cell division are summarised in Table 1 and compared to the currently closest neighbours A. californiensis and P. piriforme. from the PVC superphylum outside of the phylum Planctomycetes (GenBank accession numbers AJ229235, NR_146840 and NR_027571). In the MLSA-based tree confidence values are given at the nodes (in \%). Six species of the family Pirellulaceae served as outgroup

Exponentially growing $\mathrm{V} 22^{\mathrm{T}}$ cells were analysed using phase contrast, SEM and TEM analysis. Cells of strain $\mathrm{V} 22^{\mathrm{T}}$ are round grain rice-shaped with an average size of $1.6 \pm 0.3 \mu \mathrm{m}$ (length) and $0.7 \pm 0.2 \mu \mathrm{m}$ (width) (Fig. 3a, c). Cells of A. californiensis $\mathrm{CA} 12^{\mathrm{T}}$ and $P$. piriforme $\mathrm{P} 3^{\mathrm{T}}$ are larger than $\mathrm{V} 22^{\mathrm{T}}$ cells. Strain $\mathrm{V} 22^{\mathrm{T}}$ forms rosettes of typically 


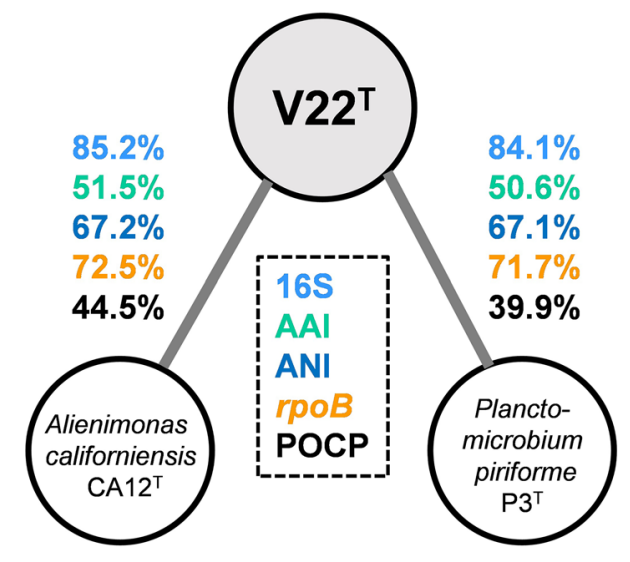

Fig. 2 Phylogenetic marker values of strain $\mathrm{V} 22^{\mathrm{T}}$ and its currently closest neighbours. The numbers give the similarity values shared between strain $\mathrm{V} 22^{\mathrm{T}}$, Alienimonas californiensis $\mathrm{CA} 12^{\mathrm{T}}$ and Planctomicrobium pirifome $\mathrm{P} 3^{\mathrm{T}}$ for $16 \mathrm{~S}$ rRNA gene sequence identity (16S), average amino acid identity (AAI), average nucleotide identity (ANI), rроB nucleotide sequence identity $(r p o B)$ and percentage of conserved proteins (POCP)

6-15 cells, which assemble to characteristic linear or slightly branched chains (Fig. 4). Crateriform structures are present on the surface of all three strains, but their distribution is different (Table 1). TEM thin sections of strain $\mathrm{V} 22^{\mathrm{T}}$ confirm a planctomycetal cell architecture with a condensed nucleoid and invaginations of the cytoplasmic membrane leading to an enlarged periplasmic space (Fig. 5). In the cytoplasm of strain $\mathrm{V} 22^{\mathrm{T}}$, cytoskeletal elements (CE) were observed (Fig. 5b-d). Such putative CEs form partly thick bundles (Fig. 5c), which seem to fill membrane cavities (Fig. 5d). The presence of such structures has been reported in Planctomycetes before (Lage et al. 2013).

The three compared strains are aerobic and motile. Strain $\mathrm{V} 22^{\mathrm{T}}$ shares pink pigmentation with A. californiensis, whereas $P$. piriforme is non-pigmented. In $\mathrm{M} 1 \mathrm{H}$ NAG ASW medium, strain $\mathrm{V} 22^{\mathrm{T}}$ was able to growth over a temperature range of $15-32{ }^{\circ} \mathrm{C}$ and a pH range of 6.0-10.0. Strain $\mathrm{V} 22^{\mathrm{T}}$ is heterotrophic with a mesophilic and slightly alkaliphilic growth profile. The new isolate originated from sediment of a seawater fish tank, which might indicate a facultatively anaerobic lifestyle. Whether growth under oxygen depletion is based on anaerobic respiration or fermentation needs further studies. The presence of menaquinone biosynthesis genes has been verified in the genome sequence, however, the production of menaquinones is not indicative of an anaerobic energy metabolism. Planctomycetales generally produce menaquinones (Sittig and Schlesner 1993). Strain $\mathrm{V} 22^{\mathrm{T}}$ harbours the gene for a cobalamin-containing methionine synthase (metH, V22_33860). Since an open reading frame encoding the cobalamin-independent variant of the essential anabolic enzyme has not been identified, the organism might be a cobalamin auxotroph that salvages $B_{12}$ vitamins from the environment.

Optimal growth of strain $\mathrm{V} 22^{\mathrm{T}}$ was observed at $30{ }^{\circ} \mathrm{C}$ and $\mathrm{pH} 8.5$ (Table 1), which led to a maximal growth rate of $0.069 \mathrm{~h}^{-1}$, corresponding to a generation time of $10 \mathrm{~h}$. While the $\mathrm{pH}$ range allowing growth of strain $\mathrm{V} 22^{\mathrm{T}}$ is similar to that of $A$. californiensis, $P$. piriforme prefers slightly acidic conditions. A. californiensis can grow up to temperatures of $36{ }^{\circ} \mathrm{C}$, while the other two strains only grew up to $30-32{ }^{\circ} \mathrm{C}$. Taken together, the three strains can be clearly differentiated using morphological and physiological properties.

Genomic characteristics and genome-based analysis of metabolic capabilities

The genome of strain $\mathrm{V} 22^{\mathrm{T}}$ has a size of $5.2 \mathrm{Mb}$ and a $\mathrm{G}+\mathrm{C}$ content of $53.9 \%$. The genome of strain $\mathrm{V} 22^{\mathrm{T}}$ and $A$. californiensis have a comparable size, whereas the genome of $P$. piriforme is $1 \mathrm{Mb}$ larger. The numbers of tRNA genes in the three strains range between 53-65. Planctomycetal genomes typically contain a high percentage of genes coding for hypothetical or uncharacterised proteins. The values are in a comparable range (39-42\%) in case of strain $\mathrm{V} 22^{\mathrm{T}}$ and A. californiensis, but lower than the $56 \%$ in $P$. piriforme. Hence, the latter has about 700 hypothetical proteins more than the other two strains. A. californiensis has a high $\mathrm{G}+\mathrm{C}$ content of $71 \%$, which is a distinctive criterion for delineation from strain $\mathrm{V} 22^{\mathrm{T}}$ and $P$. piriforme, which have a moderate $\mathrm{G}+\mathrm{C}$ content of $54-59 \%$.

Based on the genome sequences of strain $\mathrm{V} 22^{\mathrm{T}}$ and the two current close neighbours, we analysed the numbers of genes coding for enzymes putatively involved in the degradation of polysaccharides (carbohydrate-active enzymes) or in biosynthetic pathways for secondary metabolites (Table 2). Carbohydrate-active enzymes could not be analyzed for $P$. piriforme as the CAZY database only lists 
Table 1 Phenotypic and genotypic features of strain $\mathrm{V} 22^{\mathrm{T}}$ compared to closely related strains

\begin{tabular}{|c|c|c|c|}
\hline Feature & $\mathrm{V} 22^{\mathrm{T}}$ & A. californiensis $\mathrm{CA} 12^{\mathrm{T}}$ & P. piriforme $\mathrm{P}^{\mathrm{T}}$ \\
\hline \multicolumn{4}{|l|}{ Phenotypic characteristics } \\
\hline Shape & Round grain rice-shaped & Spherical to ovoid & Ellipsoid to pear-shaped \\
\hline Length $[\mu \mathrm{m}]$ & $1.6 \pm 0.3$ & $2.0 \pm 0.2$ & $1.7-2.8$ \\
\hline Width $[\mu \mathrm{m}]$ & $0.7 \pm 0.2$ & $1.5 \pm 0.3$ & $0.9-1.3$ \\
\hline Colour & Pink & Pink & White \\
\hline Relation to oxygen & Aerobic & Aerobic & Aerobic \\
\hline Temperature range (optimum) $\left[{ }^{\circ} \mathrm{C}\right]$ & $15-32(30)$ & $10-36(27)$ & $10-30(20-28)$ \\
\hline $\mathrm{pH}$ range (optimum) & $6.0-10.0(8.5)$ & $6.0-9.0(7.5)$ & $4.2-7.1(6.0-6.5)$ \\
\hline Division & Budding & Budding & Budding \\
\hline Dimorphic life cycle & No & No & Yes \\
\hline Motility & Yes & Yes & Yes \\
\hline Crateriform structures & Overall & $\begin{array}{l}\text { Overall, except for the pole at } \\
\text { which the flagellum is located }\end{array}$ & At reproductive pole \\
\hline Fimbriae & Few & Yes, polar & n.d. \\
\hline Capsule & n.o. & n.o. & n.d. \\
\hline Stalk & Short, opposite of budding pole & n.o. & Yes \\
\hline Holdfast structure & n.o. & n.o. & n.d. \\
\hline \multicolumn{4}{|l|}{ Genomic characteristics } \\
\hline Genome size $[\mathrm{bp}]$ & $5,163,473$ & $5,475,215$ & $6,317,004$ \\
\hline $\mathrm{G}+\mathrm{C}[\%]$ & 53.9 & 70.7 & 58.8 \\
\hline Coding density $[\%]$ & 87.8 & 88.5 & 85.8 \\
\hline Completeness [\%] & 94.8 & 94.8 & 95.7 \\
\hline Contamination $[\%]$ & 0 & 0 & 1.72 \\
\hline Total genes & 4,376 & 4,382 & 5,117 \\
\hline Protein-coding genes & 4,301 & 4,309 & 5,050 \\
\hline Hypothetical proteins & 1,673 & 1,798 & 2,814 \\
\hline $16 \mathrm{~S}$ rRNA genes & 2 & 2 & 1 \\
\hline tRNA genes & 64 & 65 & 53 \\
\hline
\end{tabular}

The genome analysis is based on GenBank accession numbers CP036316 (V22 $\left.{ }^{\mathrm{T}}\right), \mathrm{CP} 036265\left({\left.\text { Alienimonas californiensis } \mathrm{CA} 12^{\mathrm{T}}\right) \text { and }}\right.$ GCA_900113665 (Planctomicrobium piriforme $\mathrm{P}^{\mathrm{T}}{ }^{\mathrm{T}}$ )

n.o. not observed, n.d. not determined

strains with complete genomes. Strain $\mathrm{V} 22^{\mathrm{T}}$ and $A$. californiensis $\mathrm{CA} 12^{\mathrm{T}}$ harbour $96-122$ carbohydrateactive enzymes and show a similar distribution pattern with regard to the different families. Approximately $60 \%$ of the identified enzymes could be assigned to the glycosyl transferase family in both strains. Numbers in the other families vary only slightly between the two strains. Numbers of predicted clusters involved in the secondary metabolism of strain $\mathrm{V} 22^{\mathrm{T}}$ are surprisingly low. The strain harbours only three terpenoid biosynthesis-related genes/gene clusters, which might be relevant for carotenoid biosynthesis in this strain. Genes coding for different types of polyketide synthases (PKSs) or non-ribosomal peptide synthetases (NRPSs) were not identified in strain $\mathrm{V} 22^{\mathrm{T}}$. The same is true for clusters putatively involved in the synthesis of ectoine, bacteriocins and resorcinol (Table 2). A. californiensis $\mathrm{CA} 12^{\mathrm{T}}$ codes for an additional type III PKS compared to strain $\mathrm{V} 22^{\mathrm{T}}$, whereas a total number of 8 clusters are present in the genome of $P$. piriforme $\mathrm{P} 3^{\mathrm{T}}$. In conclusion, strain $\mathrm{V} 22^{\mathrm{T}}$ either produces only a very small set of 

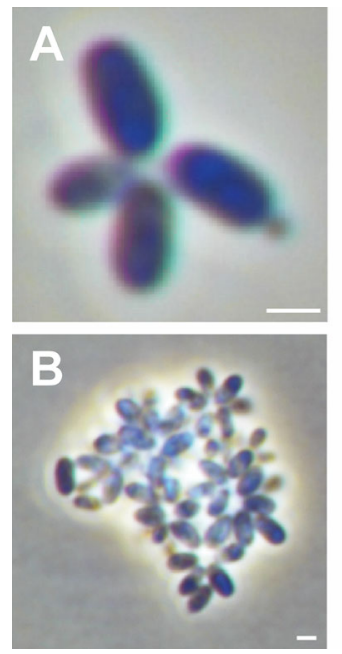

\section{C}

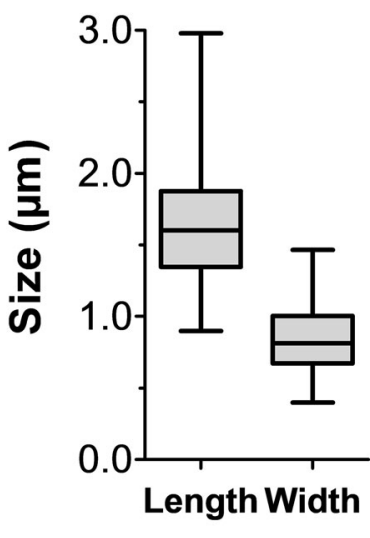

Fig. 3 Light microscopy images and cell size plot of strain $\mathrm{V} 22^{\mathrm{T}}$. The mode of cell division (A) and a general overview of cell morphology (B) is shown in the pictures. The scale bar is $1 \mu \mathrm{m}$. For determination of the cell size (C) at least 100 representative cells were counted manually or by using a semiautomated object count tool secondary metabolites or harbours as yet uncharacterised clusters which escaped the bioinformatic prediction.

Taken together, the observed differences during comparison of morphological and genomic features of strain $\mathrm{V} 22^{\mathrm{T}}$ and its neighbours support the results of the phylogenetic analysis, which delineate strain $\mathrm{V} 22^{\mathrm{T}}$ from members of the genera Alienimonas and Planctomicrobium. We thus conclude that strain $\mathrm{V} 22^{\mathrm{T}}$ should be classified as the type strain of a novel species within a novel genus, for which we propose the name Calycomorphotria gen. nov., with the type species Calycomorphotria hydatis sp. nov.

\section{Calycomorphotria gen. nov.}

Ca.ly.co.mor.pho'tri.a. Gr. n. kalyx a bud; Gr. fem. n. morphotria a creator; N.L. fem. n. Calycomorphotria, a bacterium that generates buds.
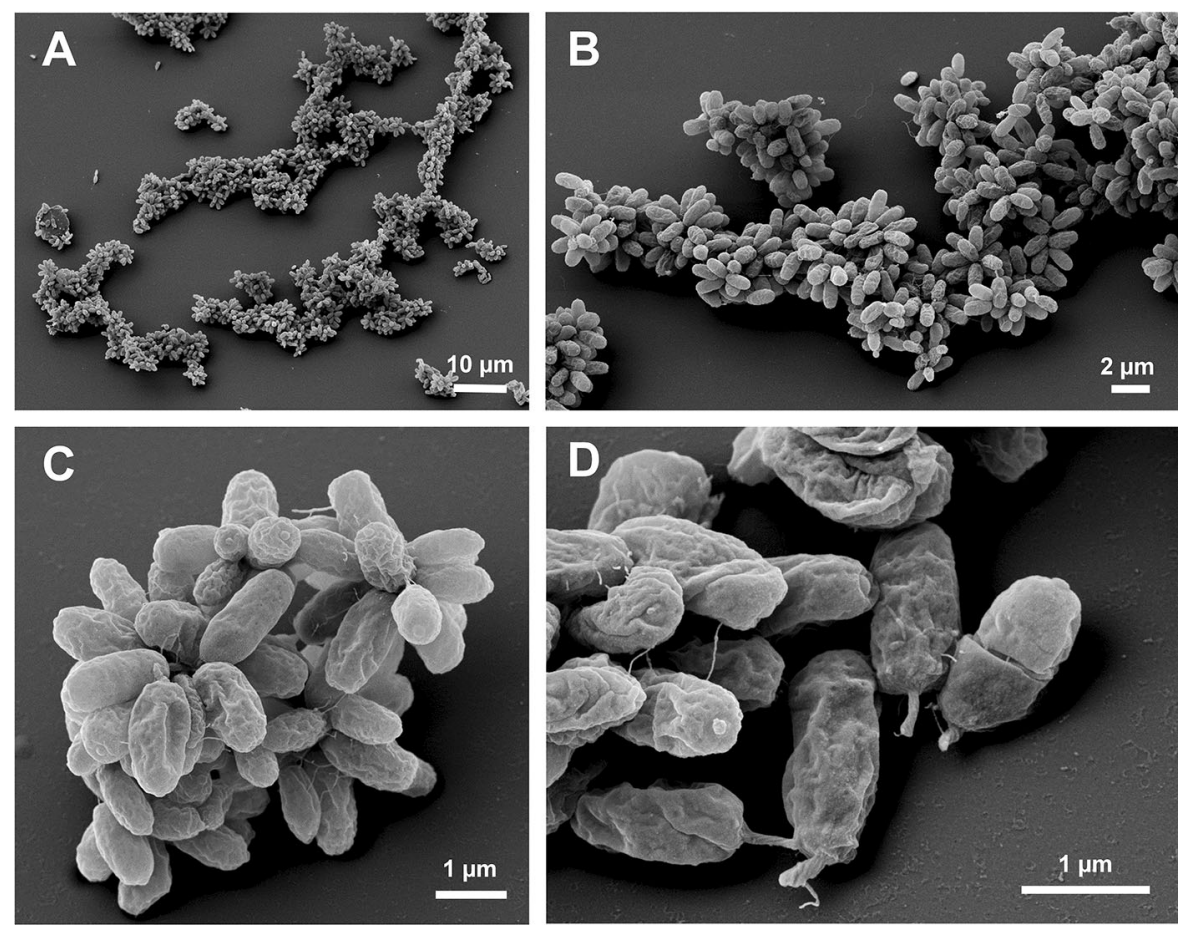

Fig. 4 Electron microscopic images of strain V22 ${ }^{\mathrm{T}}$. Cells of strain $\mathrm{V} 22^{\mathrm{T}}$ form rosettes typically comprising 6-15 cells. The rosettes assemble to linear or slightly branched chains. Separate scale bars are presented in each of the images 

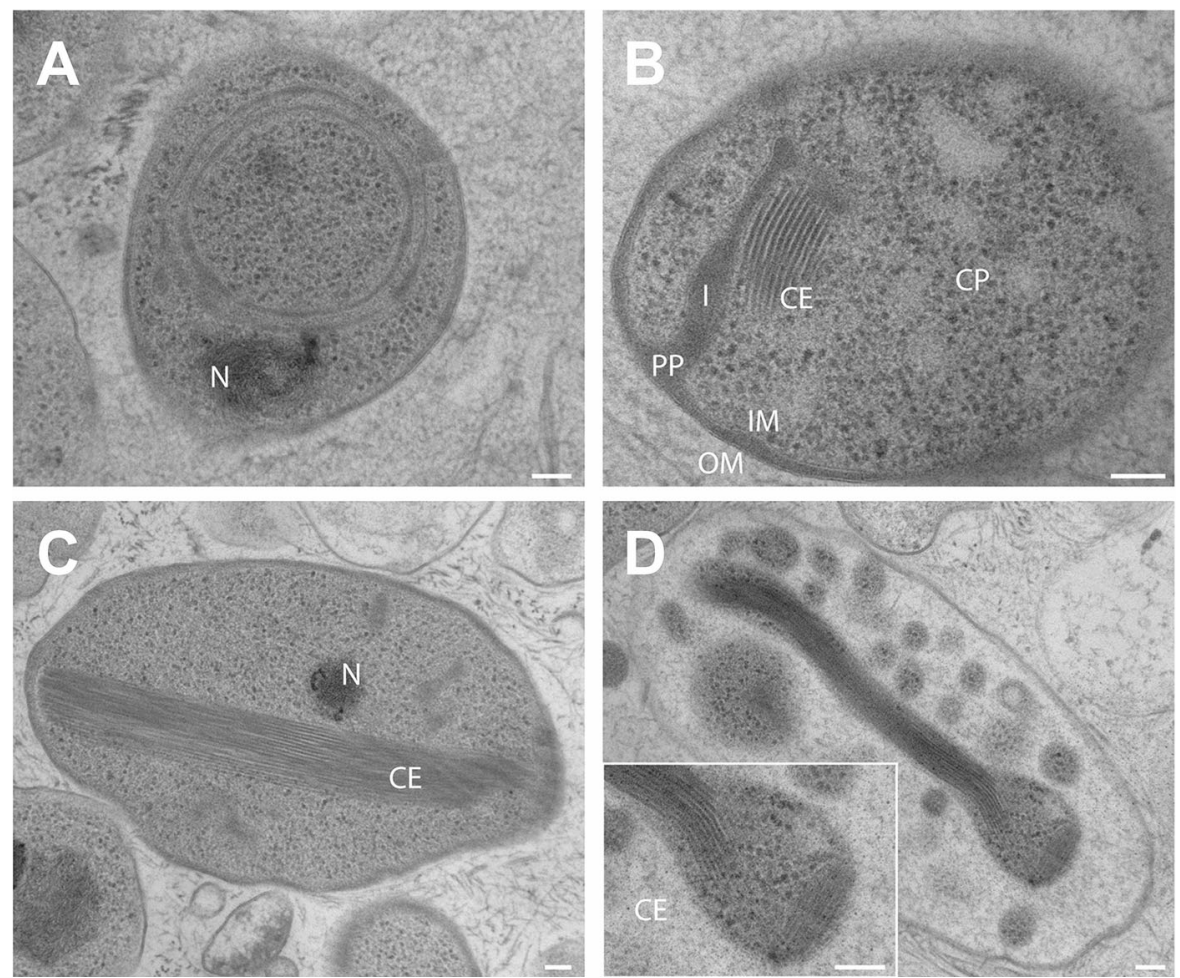

Fig. 5 Transmission electron microscopy images of strain $\mathrm{V} 22^{\mathrm{T}}$. TEM images of thin sections showing the cell morphology of strain $\mathrm{V} 22^{\mathrm{T}}$. Abbreviations: CE: (potential)

cytoskeletal elements, CP cytoplasm, I invagination, IM inner membrane, OM outer membrane, $\mathrm{PP}$ periplasmic space, $\mathrm{N}$ condensed nucleoid. The scale bar is $0.1 \mu \mathrm{m}$
Table 2 Genome-based analysis of carbohydrateactive enzymes and secondary metaboliterelated gene clusters

The genome analysis is based on GenBank accession numbers CP036316 (V22 $\left.{ }^{\mathrm{T}}\right)$, CP036265 (Alienimonas californiensis $\mathrm{CA} 12^{\mathrm{T}}$ ) and GCA_900113665 (Planctomicrobium piriforme $\mathrm{P}^{\mathrm{T}}$ ); n.d. not determined

\begin{tabular}{llll}
\hline Feature & V22 & $\begin{array}{l}\text { A. californiensis } \\
\mathrm{CA} 12^{\mathrm{T}}\end{array}$ & $\begin{array}{l}\text { P. piriforme } \\
\mathrm{P}^{\mathrm{T}}\end{array}$ \\
\hline Genome size (Mb) & 5.16 & 5.48 & 6.32 \\
Carbohydrate-active enzymes & & & \\
Glycoside hydrolase family & 23 & 28 & n.d. \\
Glycosyl transferase family & 53 & 71 & n.d. \\
Polysaccharide lyase family & 2 & 6 & n.d. \\
Carbohydrate esterase family & 10 & 11 & n.d. \\
Carbohydrate-binding module family & 8 & 6 & n.d. \\
Total & 96 & 122 & n.d. \\
Secondary metabolite-related gene clusters & & & \\
Terpenoid & 3 & 3 & 4 \\
Type I PKS & 0 & 0 & 1 \\
Type II PKS & 0 & 0 & 0 \\
Type III PKS & 0 & 1 & 1 \\
NRPS & 0 & 0 & 0 \\
Bacteriocin & 0 & 0 & 2 \\
Ectoine & 0 & 0 & 0 \\
Resorcinol & 0 & 0 & 0 \\
Total & 3 & 4 & 8 \\
\hline
\end{tabular}


Members of the genus have a Gram-negative cell envelope architecture, are motile aerobic heterotrophs with a mesophilic, neutrophilic or slightly alkaliphilic growth profile. Cells are round grain rice-shaped, divide by budding and contain fimbriae and crateriform structures. The genus belongs to the family Planctomycetaceae, order Planctomycetales, class Planctomycetia, phylum Planctomycetes. The type species of this genus is Calycomorphotria hydatis.

\section{Calycomorphotria hydatis sp. nov.}

hy'da.tis. Gr. n. hydor, -atos water; N.L. gen. n. hydatis of water; corresponding to the origin of the type strain from an aquatic environment.

Cells have an average size of $1.6 \pm 0.3 \times 0.7 \pm 0.2 \mu \mathrm{m}$ and form rosettes typically consisting of $6-15$ cells. Rosettes assemble into linear or slightly branched aggregates. Cells contain crateriform structures covering the entire cell surface and a short stalk opposite of the budding pole. The cell plan features a condensed nucleoid, invaginations of the cytoplasmic membrane and cytoskeletal elements in the cytoplasm. Colonies are pink. Grows at ranges of $15-32{ }^{\circ} \mathrm{C}$ (optimum $30{ }^{\circ} \mathrm{C}$ ) and at $\mathrm{pH}$ 6.0-10.0 (optimum 8.5). The $\mathrm{G}+\mathrm{C}$ content of the type strain is $53.9 \%$.

The type strain, V22 ${ }^{\mathrm{T}}\left(\mathrm{DSM} 29767^{\mathrm{T}}=\mathrm{LMG}\right.$ $29080^{\mathrm{T}}$ ), was isolated from water and sediment of a seawater fish tank in June 2013. The type strain genome (acc. no. CP036316) and 16S rRNA gene sequence (acc. no. MK554537) are available from GenBank. The genome size of the type strain is $5,163,473$ bp.

Acknowledgements Open Access funding provided by Projekt DEAL. Part of this research was funded by the Deutsche Forschungsgemeinschaft grants KA 4967/1-1 and JO 893/4-1, grant ALWOP.308 of the Nederlandse Organisatie voor Wetenschappelijk Onderzoek (NWO), SIAM (Soehngen Institute for Anaerobic Microbiology) grant no. 024002002 and the Radboud Excellence fellowship. We thank Ina Schleicher for skilful technical assistance. Brian Tindall and Regine Fähnrich from the DSMZ as well as the BCCM/LMG Bacteria collection we thank for support during strain deposition. We are grateful to Elizabeth Benecchi from Harvard Medical School, EM facility, for supporting thin section and TEM observations.

Author contributions T.S. and N.K. wrote the manuscript and analysed genome-encoded features, S.W. performed the phylogenetic analysis, A.H. and M.J. isolated the strains and performed the initial cultivation and strain deposition, S.H.P. and C.B. performed the light microscopic analysis and prepared the pictures, C.B. produced thin sections and analysed them by TEM. M.S.M.J. contributed to text preparation and revised the manuscript, M.R. performed the electron microscopic analysis and prepared the SEM pictures, C.J. supervised A.H. and C.B. and planned and managed the study. All authors read and approved the final version of the manuscript.

\section{Compliance with ethical standards}

Conflict of interest The authors declare that they have no conflict of interest.

Ethical statement This article does not contain any studies with animals performed by any of the authors.

Open Access This article is licensed under a Creative Commons Attribution 4.0 International License, which permits use, sharing, adaptation, distribution and reproduction in any medium or format, as long as you give appropriate credit to the original author(s) and the source, provide a link to the Creative Commons licence, and indicate if changes were made. The images or other third party material in this article are included in the article's Creative Commons licence, unless indicated otherwise in a credit line to the material. If material is not included in the article's Creative Commons licence and your intended use is not permitted by statutory regulation or exceeds the permitted use, you will need to obtain permission directly from the copyright holder. To view a copy of this licence, visit http://creativecommons.org/licenses/by/4.0/.

\section{References}

Bengtsson MM, Øvreås L (2010) Planctomycetes dominate biofilms on surfaces of the kelp Laminaria hyperborea. BMC Microbiol 10:261

Blin K, Wolf T, Chevrette MG, Lu X, Schwalen CJ, Kautsar SA, Suarez Duran HG, de Los Santos EL, Kim HU, Nave M (2017) antiSMASH 4.0-improvements in chemistry prediction and gene cluster boundary identification. Nucleic Acids Res 45:W36-W41

Boedeker C, Schuler M, Reintjes G, Jeske O, van Teeseling MC, Jogler M, Rast P, Borchert D, Devos DP, Kucklick M, Schaffer M, Kolter R, van Niftrik L, Engelmann S, Amann R, Rohde M, Engelhardt H, Jogler C (2017) Determining the bacterial cell biology of Planctomycetes. Nat Commun 8:14853

Boersma AS, Kallscheuer N, Wiegand S, Rast P, Peeters SH, Mesman RJ, Heuer A, Boedeker C, Jetten MS, Rohde M, Jogler M (2019) Alienimonas californiensis gen. nov. sp. nov., a novel Planctomycete isolated from the kelp forest in Monterey Bay. Antonie van Leeuwenhoek. Jogler C. https://doi.org/10.1007/s10482-019-01367-4

Bondoso J, Balague V, Gasol JM, Lage OM (2014) Community composition of the Planctomycetes associated with different macroalgae. FEMS Microbiol Ecol 88:445-456

Bondoso J, Godoy-Vitorino F, Balague V, Gasol JM, Harder J, Lage OM (2017) Epiphytic Planctomycetes communities 
associated with three main groups of macroalgae. FEMS Microbiol Ecol 93:fiw255

Bondoso J, Harder J, Lage OM (2013) rpoB gene as a novel molecular marker to infer phylogeny in Planctomycetales. Antonie van Leeuwenhoek 104:477-488

Castresana J (2000) Selection of Conserved Blocks from Multiple Alignments for Their Use in Phylogenetic Analysis. Mol Biol Evol 17:540-552

Dedysh SN, Henke P, Ivanova AA, Kulichevskaya IS, Philippov DA, Meier-Kolthoff JP, Göker M, Huang S, Overmann J (2019a) 100-year-old enigma solved: identification, genomic characterization and biogeography of the yet uncultured Planctomyces bekefii. Environ Microbiol 22:198-211

Dedysh, SN, Kulichevskaya IS, Beletsky AV, Ivanova AA, Rijpstra WIC, Damsté JSS, Mardanov AV, Ravin NV (2019b) Lacipirellula parvula gen. nov., sp. nov., representing a lineage of Planctomycetes widespread in lowoxygen habitats, description of the family Lacipirellulaceae fam. nov. and proposal of the orders Pirellulales ord. nov., Gemmatales ord. nov. and Isosphaerales ord. nov. Syst Appl Microbiol 43: 126050.

Devos DP (2014a) PVC bacteria: variation of, but not exception to, the gram-negative cell plan. Trends Microbiol 22:14-20

Devos DP (2014b) Re-interpretation of the evidence for the PVC cell plan supports a gram-negative origin. Antonie van Leeuwenhoek 105:271-274

Edgar RC (2004) MUSCLE: multiple sequence alignment with high accuracy and high throughput. Nucleic Acids Res 32:1792-1797

Jeske O, Jogler M, Petersen J, Sikorski J, Jogler C (2013) From genome mining to phenotypic microarrays: Planctomycetes as source for novel bioactive molecules. Antonie van Leeuwenhoek 104:551-567

Jeske O, Schüler M, Schumann P, Schneider A, Boedeker C, Jogler M, Bollschweiler D, Rohde M, Mayer C, Engelhardt H, Spring S, Jogler C (2015) Planctomycetes do possess a peptidoglycan cell wall. Nat Commun 6:7116

Jogler C, Glockner FO, Kolter R (2011) Characterization of Planctomyces limnophilus and development of genetic tools for its manipulation establish it as a model species for the phylum Planctomycetes. Appl Environ Microbiol 77:5826-5829

Jogler C, Waldmann J, Huang X, Jogler M, Glöckner FO, Mascher T, Kolter R (2012) Identification of proteins likely to be involved in morphogenesis, cell division, and signal transduction in Planctomycetes by comparative genomics. J Bacteriol 194:6419-6430

Jogler M, Jogler C (2013) Towards the development of genetic tools for Planctomycetes. In: Fuerst JA (ed) Planctomycetes: cell structure. Springer, Origins and Biology, pp 141-164

Kallscheuer N, Jogler M, Wiegand S, Peeters SH, Heuer A, Boedeker C, Jetten MS, Rohde M, Jogler C (2019) Three novel Rubripirellula species isolated from plastic particles submerged in the Baltic Sea and the estuary of the river Warnow in northern Germany. Antonie van Leeuwenhoek. https://doi.org/10.1007/s10482-019-01368-3

Kallscheuer, N, Wiegand S, Heuer A, Rensink S, Boersma AS, Jogler M, Boedeker C, Peeters SH, Rast P, Jetten MS, Rohde M, Jogler C (2020) Blastopirellula retiformator sp. nov. isolated from the shallow-sea hydrothermal vent system close to Panarea Island. Antonie van Leeuwenhoek, https://doi.org/10.1007/s10482-019-01377-2

Kallscheuer, N, Wiegand S, Peeters SH, Jogler M, Boedeker C, Heuer A, Rast P, Jetten MS, Rohde M, Jogler C (2019b) Description of three bacterial strains belonging to the new genus Novipirellula gen. nov., reclassificiation of Rhodopirellula rosea and Rhodopirellula caenicola and readjustment of the genus threshold of the phylogenetic marker rpoB for Planctomycetaceae. Antonie van Leeuwenhoek, https://doi.org/10.1007/s10482-019-01374-5

Kohn T, Wiegand S, Boedeker C, Rast P, Heuer A, Schüler M, Rohde C, Müller R-W, Brümmer F, Rohde M, Engelhardt H, Jogler M, Jogler C (2019) Planctopirus ephydatiae, a novel planctomycetal species isolated from a freshwater sponge. Syst Appl Microbiol 43:126022

Konstantinidis KT, Tiedje JM (2005) Towards a genome-based taxonomy for prokaryotes. J Bacteriol 187:6258-6264

Lachnit T, Fischer M, Kunzel S, Baines JF, Harder T (2013) Compounds associated with algal surfaces mediate epiphytic colonization of the marine macroalga Fucus vesiculosus. FEMS Microbiol Ecol 84:411-420

Lage OM, Bondoso J, Lobo-da-Cunha A (2013) Insights into the ultrastructural morphology of novel Planctomycetes. Antonie van Leeuwenhoek 104:467-476

Lage OM, van Niftrik L, Jogler C, Devos DP (2019) Planctomycetes. In: Thomas M. Schmidt (ed) Reference module in life sciences, Elsevier, pp.614-626. 4th edn https://doi.org/ 10.1016/B978-0-12-809633-8.90689-7

Lechner M, Findeiss S, Steiner L, Marz M, Stadler PF, Prohaska SJ (2011) Proteinortho: detection of (co-)orthologs in large-scale analysis. BMC Bioinform 12:124

Lee I, Ouk Kim Y, Park SC, Chun J (2016) OrthoANI: An improved algorithm and software for calculating average nucleotide identity. Int $\mathbf{J}$ Syst Evol Microbiol 66:1100-1103

Lombard V, Golaconda Ramulu H, Drula E, Coutinho PM, Henrissat B (2014) The carbohydrate-active enzymes database (CAZy) in 2013. Nucleic Acids Res 42:D490 D495

Peeters SH, van Niftrik L (2018) Trending topics and open questions in anaerobic ammonium oxidation. Curr Opin Chem Biol 49:45-52

Peeters SH, Wiegand S, Kallscheuer N, Jogler M, Heuer A, Jetten MS, Rast P, Boedeker C, Rohde M, Jogler C (2020) Three marine strains constitute the novel genus and species Crateriforma conspicua in the phylum Planctomycetes. Antonie van Leeuwenhoek. https://doi.org/10.1007/ s10482-019-01375-4

Pilhofer M, Rappl K, Eckl C, Bauer AP, Ludwig W, Schleifer KH, Petroni G (2008) Characterization and evolution of cell division and cell wall synthesis genes in the bacterial phyla Verrucomicrobia, Lentisphaerae, Chlamydiae, and Planctomycetes and phylogenetic comparison with rRNA genes. J Bacteriol 190:3192-3202

Price MN, Dehal PS, Arkin AP (2009) FastTree: computing large minimum evolution trees with profiles instead of a distance matrix. Mol Biol Evol 26:1641-1650

Pruesse E, Peplies J, Glöckner FO (2012) SINA: accurate highthroughput multiple sequence alignment of ribosomal RNA genes. Bioinformatics 28:1823-1829 
Qin Q-L, Xie B-B, Zhang X-Y, Chen X-L, Zhou B-C, Zhou J, Oren A, Zhang Y-Z (2014) A proposed genus boundary for the prokaryotes based on genomic insights. J Bacteriol 196:2210-2215

Rast, P, Glockner I, Boedeker C, Jeske O, Wiegand S, Reinhardt R, Schumann P, Rohde M, Spring S, Glockner FO, Jogler C, Jogler M (2017) Three Novel Species with Peptidoglycan Cell Walls form the New Genus Lacunisphaera gen. nov. in the Family Opitutaceae of the Verrucomicrobial Subdivision 4. Front Microbiol 8: 202

Ravin NV, Rakitin AL, Ivanova AA, Beletsky AV, Kulichevskaya IS, Mardanov AV, Dedysh SN (2018) Genome analysis of Fimbriiglobus ruber SP5T, a planctomycete with confirmed chitinolytic capability. Appl Environ Microbiol 84:e02645-e2717

Rensink, S, Wiegand S, Kallscheuer N, Rast P, Peeters SH, Heuer A, Boedeker C, Jetten MS, Rohde M, Jogler M, Jogler C (2020) Description of the novel planctomycetal genus Bremerella, containing Bremerella volcania $\mathrm{sp}$. nov., isolated from an active volcanic site, and reclassification of Blastopirellula cremea as Bremerella cremea comb. nov. Antonie van Leeuwenhoek. https://doi.org/10. 1007/s10482-019-01378-1

Rivas-Marin E, Canosa I, Santero E, Devos DP (2016) Development of genetic tools for the manipulation of the planctomycetes. Front Microbiol 7:914

Rodriguez-R LM, Konstantinidis KT (2016) The enveomics collection: a toolbox for specialized analyses of microbial genomes and metagenomes. PeerJ Preprints 4:e1900v1

Sievers F, Wilm A, Dineen D, Gibson TJ, Karplus K, Li W, Lopez R, McWilliam H, Remmert M, Söding J (2011) Fast, scalable generation of high-quality protein multiple sequence alignments using Clustal Omega. Mol Syst Biol 7:539

Sittig M, Schlesner H (1993) Chemotaxonomic investigation of various prosthecate and/or budding bacteria. Syst Appl Microbiol 16:92-103

Stamatakis A (2014) RAxML version 8: a tool for phylogenetic analysis and post-analysis of large phylogenies. Bioinformatics 30:1312-1313
Strous M, Fuerst JA, Kramer EH, Logemann S, Muyzer G, van de Pas-Schoonen KT, Webb R, Kuenen JG, Jetten MS (1999) Missing lithotroph identified as new planctomycete. Nature 400:446-449

van Niftrik L, Devos DP (2017) Planctomycetes-Verrucomicrobia-Chlamydiae bacterial superphylum: new model organisms for evolutionary cell biology. Front Microbiol 8:1458

van Teeseling MC, Mesman RJ, Kuru E, Espaillat A, Cava F, Brun YV, VanNieuwenhze MS, Kartal B, van Niftrik L (2015) Anammox Planctomycetes have a peptidoglycan cell wall. Nat Commun 6:6878

Vollmers J, Frentrup M, Rast P, Jogler C, Kaster AK (2017) Untangling genomes of novel planctomycetal and verrucomicrobial species from monterey bay kelp forest metagenomes by refined binning. Front Microbiol 8:472

Wiegand S, Jogler M, Boedeker C, Pinto D, Vollmers J, RivasMarín E, Kohn T, Peeters SH, Heuer A, Rast P, Oberbeckmann S, Bunk B, Jeske O, Meyerdierks A, Storesund JE, Kallscheuer N, Lücker S, Lage OM, Pohl T, Merkel BJ, Hornburger P, Müller R-W, Brümmer F, Labrenz M, Spormann AM, Op den Camp HJM, Overmann J, Amann R, Jetten MSM, Mascher T, Medema MH, Devos DP, Kaster A-K, Øvreås L, Rohde M, Galperin MY, Jogler C (2020) Cultivation and functional characterization of 79 planctomycetes uncovers their unique biology. Nat Microbiol 5:126-140

Wiegand S, Jogler M, Jogler C (2018) On the maverick Planctomycetes. FEMS Microbiol Rev 42:739-760

Yarza P, Yilmaz P, Pruesse E, Glöckner FO, Ludwig W, Schleifer KH, Whitman WB, Euzeby J, Amann R, RosselloMora R (2014) Uniting the classification of cultured and uncultured bacteria and archaea using 16S rRNA gene sequences. Nat Rev Microbiol 12:635-645

Publisher's Note Springer Nature remains neutral with regard to jurisdictional claims in published maps and institutional affiliations. 